18. Bader $G$, Lejeune $S$, Messner M. Reduction of cyclosporine-induced gingival overgrowth following a change to tacrolimus. A case history involving a liver transplant patient. J Periodontol 1998; 69: 729-732.

19. Moher D, Liberati A, Tetzlaff J, Altman D G, The P G Preferred reporting items for systematic reviews and meta-analyses: The PRISMA statement. PLOS Medicine 2009; 6: e1000097.

20. Higgins J P T. Cochrane handbook for systematic reviews of interventions. Chapter 10. Cochrane Collaboration, 2011.

21. National Heart, Lung, and Blood Institute. Development and use of quality assessment tools. Available online at www.nhlbi.nih.gov/health-topics/study-qualityassessment-tools (accessed 2 January 2020)

22. Koppen I J, Kuizenga-Wessel S, Saps M et al. Functional defecation disorders and excessive body weight: $A$ Systematic review. Pediatrics 2016; 138.

23. Helenius-Hietala J, Ruokonen H, Gronroos L et al. Self-reported oral symptoms and signs in liver transplant recipients and a control population. Liver Transp/ 2013; 19: 155-163.

24. Aimetti M, Romano F, Marsico A, Navone R. Nonsurgical periodontal treatment of cyclosporin A-induced gingival overgrowth: immunohistochemical results. Oral Dis 2008; 14: 244-250.

25. Oettinger-Barak O, Barak S, Machtei E E et al. Periodontal changes in liver cirrhosis and posttransplantation patients. I: clinical findings. J Periodonto 2001; 72: 1236-1240.

26. Ferrazzano G F, Sangianantoni G, Cantile $T$, Iorio $R$, Ingenito A. Oral health status in liver transplant Italian children. Eur J Paediatr Dent 2013; 14: 323-327.

27. Davidovich E, Asher R, Shapira J et al. Mucosal pH, dental findings, and salivary composition in pediatric liver transplant recipients. Transplantation 2013; 96: 102-107.

28. Lin Y T, Yang F T. Gingival enlargement in children administered cyclosporine after liver transplantation. J Periodontol 2010; 81: 1250-1255.

29. Sheehy E C, Roberts G J, Beighton D, O'Brien G. Oral health in children undergoing liver transplantation. Int J Paediatr Dent 2000: 10: 109-119.

30. Ross P J, Nazif M M, Zullo T, Zitelli B, Guevara P. Effect of Cyclosporin A on gingival status following liver transplantation. ASDC J Dent Child 1989; 56: 56-59.

31. Kauffels A, Schmalz G, Kollmar $O$ et al. Oral findings and dental behaviour before and after liver transplantation - a single-centre cross-sectional study. Int Dent J 2017; 67: 244-251.

32. Castellanos-Cosano L, Machuca-Portillo G, SeguraSampedro J J et al. Prevalence of apical periodontitis and frequency of root canal treatments in liver transplant candidates. Med Oral Patol Oral Cir Bucal 2013; 18 e773-779.

33. Rakauskaite A, Juodzbalys G, Pauza D H, Cicciu M. Green pigmentation in human teeth. A stereomicroscopic study. J Clin Pediatr Dent 2014; 38: 355-361.
34. Zaia A A, Graner E, de Almeida O P, Scully C. Oral changes associated with biliary atresia and liver transplantation. J Clin Pediatr Dent 1993; 18: 38-42.

35. Sommer S, Magagnin K, Kramer P F, Tovo M F, Bervian J. Green teeth associated with neonatal hyperbilirubinemia caused by biliary atresia: review and case report. J Clin Pediatr Dent 2010; 35: 199-202.

36. Crombie F, Manton D, Kilpatrick N. Aetiology of molar-incisor hypomineralization: a critical review. Int Paediatr Dent 2009; 19: 73-83.

37. Page R C, Kornman K S. The pathogenesis of human periodontitis: an introduction. Periodontol 2000 1997; 14: $9-11$.

38. Diaz-Ortiz M L, Mico-Llorens J M, Gargallo-Albiol J et al. Dental health in liver transplant patients. Med Oral Patol Oral Cir Bucal 2005; 10: 72-76; 66-72.

39. Bassiri A G, Girgis R E, Theodore J. Actinomyces odontolyticus thoracopulmonary infections. Two cases in lung and heart-lung transplant recipients and a review of the literature. Chest 1996: 109: 1109-1111.

40. Seymour G J, Ford P J, Cullinan M P, Leishman S, Yamazaki K. Relationship between periodontal infections and systemic disease. Clin Microbiol Infect 2007; 13 Suppl 4: 3-10.

41. Kao R T, Lee S, Harpenau L. Clinical challenges in diagnosing and monitoring periodontal inflammation. Calif Dent Assoc 2010; 38: 263-270.

42. Alani A, Seymour R. Systemic medication and the inflammatory cascade. Periodontol 2000 2014; 64: 198-210.

43. Daley T D, Wysocki G P, Day C. Clinical and pharmacologic correlations in cyclosporine-induced gingival hyperplasia. Oral Surg Oral Med Oral Pathol 1986; 62: 417-421.

44. Guggenheimer J, Eghtesad B, Close J M, Shay C, Fung $\mathrm{J} J$. Dental health status of liver transplant candidates. Liver Transp/ 2007; 13: 280-286.

45. Somacarrera M L, Hernandez G, Acero J, Moskow B S. Factors related to the incidence and severity of cyclosporininduced gingival overgrowth in transplant patients. A longitudinal study. J Periodontol 1994; 65: 671-675.

46. Liu Z, Chen Y, Tao R et al. Tacrolimus-based versus cyclosporine-based immunosuppression in hepatitis $C$ virus-infected patients after liver transplantation: meta-analysis and systematic review. PLOS One 2014 9: e107057.

47. Helenius-Hietala J, Ruokonen $\mathrm{H}$, Gronroos L et al. Oral mucosal health in liver transplant recipients and controls. Liver Transp/ 2014; 20: 72-80.

48. Squires $\mathrm{R} \mathrm{H}, \mathrm{Ng}$ V, Romero R et al. Evaluation of the pediatric patient for liver transplantation: 2014 practice guideline by the American Association for the Study of Liver Diseases, American Society of Transplantation and the North American Society for Pediatric Gastroenterology, Hepatology, and Nutrition. J Pediatr Gastroenterol Nutr 2014; 59: 112-131.
49. Greene J C, Vermillion J R. The simplified oral hygiene index. J Am Dent Assoc 1964; 68: 7-13.

50. Loe $H$, Silness J. Periodontal disease in pregnancy I. Prevalence and severity. Acta Odontol Scand 1963; 21: 533-551.

51. O'Leary T J, Drake R B, Naylor J E. The plaque contro record. J Periodontol 1972; 43: 38.

52. Franco $E$, Saunders $C P$, Roberts $G$ J, Suwanprasit $A$. Dental disease, caries related microflora and salivary IgA of children with severe congenital cardiac disease: an epidemiological and oral microbial survey. Pediatr Dent 1996; 18: 228-235.

53. World Health Organisation. Oral health surveys: basic methods. Geneva; Albany, NY: World Health Organization; WHO Publications Center USA [distributor], 1987.

54. Silness J, Löe H. Periodontal disease in pregnancy. ii. Correlation between oral hygiene and periodontal condtion. Acta Odontol Scand 1964; 22: 121-135.

55. Löe H. The gingival index, the plaque index and the retention index systems. J Periodontol 1967; 38 Suppl: 610-616.

56. Seymour R A, Smith D G, Turnbull D N. The effects of phenytoin and sodium valproate on the periodontal health of adult epileptic patients. J Clin Periodonto 1985; 12: 413-419.

57. Ainamo J, Bay I. Problems and proposals for recording gingivitis and plaque. Int Dent J 1975; 25: 229-235.

58. Iwakura M, Shibuya Y, Yasuno Y Y. Scoring method of nifedipine induced gingiva hyperplasia. J Dent Health 1990; 40: 576-577.

59. Greene J, Vermillion J. The oral hygiene index: a method for classifying oral hygiene status. J Am Dent Assoc 1960; 61: 172-179.

60. Petersen P E, Bourgeois D, Bratthall D, Ogawa H. Oral health information systems-towards measuring progress in oral health promotion and disease prevention. Bull World Health Organ 2005; 83: 686-693.

61. Clarkson J, O'Mullane D. A modified DDE Index for use in epidemiological studies of enamel defects. J Dent Res 1989: 68: 445-450

62. Lindy O, Suomalainen $K$, Mäkelä M, Lindy S. Statin use is associated with fewer periodontal lesions: $A$ retrospective study. BMC Oral Health 2008: 8: 16 .

63. Lange D E, Plagmann H C, Eenboom A, Promesberger A. Clinical methods for the objective evaluation of oral hygiene. Dtsch Zahnarztl Z 1977; 32: 44-47.

64. Page R C, Eke P I. Case definitions for use in populationbased surveillance of periodontitis. J Periodonto/ 2007; 78: 1387-1399.

65. Diamanti-Kipioti A, Papapanou P N, Moraitaki-Tsami A, Lindhe J, Mitsis F. Comparative estimation of periodontal conditions by means of different index systems. J Clin Periodontol 1993: 20: 656-661.

66. World Health Organization. Oral health surveys: basic methods. Geneva: World Health Organization, 1997.

\title{
Correction to: Periodontal care in general practice: 20 important FAQs - Part two
}

The original article can be found online at https://doi.org/10.1038/s41415-019-0944-9

Author's correction note:

Clinical article Br Dent J 2019; 227: 875-880.

When this article was initially published, the following boxes in Table 1 were incorrect:

- In the top row of the Dosage column, 'Doxycyline $200 \mathrm{mg}$ (loading dose), $100 \mathrm{mg}$ OD for 14 days' should have read 'Doxycyline $200 \mathrm{mg}$ (loading dose), $100 \mathrm{mg}$ OD for 21 days'

- In the top row of the Avoid column, 'oral contraceptives less effective' should have been removed as this is no longer correct.

The authors apologise for any confusion caused. 